Editorial

\title{
Coproducing Urban Governance
}

\author{
Liz Richardson ${ }^{1, *}$, Catherine Durose ${ }^{2}$ and Beth Perry ${ }^{3}$ \\ ${ }^{1}$ Politics Department, University of Manchester, Manchester, M13 9PL, UK; E-Mail: liz.richardson@manchester.ac.uk \\ 2 Institute of Local Government Studies, University of Birmingham, Birmingham, B15 2TT, UK; E-Mail: c.durose@bham.ac.uk \\ ${ }^{3}$ Urban Institute and Urban Studies and Planning, University of Sheffield, Sheffield, S10 2TN, UK; \\ E-Mail: b.perry@sheffield.ac.uk \\ * Corresponding author
}

Submitted: 19 March 2018 | Published: 3 April 2018

\begin{abstract}
There are many critiques of existing forms of urban governance as not fit for purpose. However, what alternatives might look like is equally contested. Coproduction is proposed as a response to address complex wicked issues. Achieving coproduction is a highly complex and daunting task. Bottom up approaches to the initiation of coproduced governance are seen as fruitful, including exemplification of utopian alternatives though local practices. New ways of seeing the role of conflict in participation are needed, including ways to institutionalise agonistic participatory practices. Coproduction in governance drives demands for forms of knowledge production that are themselves coproductive. New urban governing spaces need to be coproduced through participative transformation requiring experimentation and innovation in re-designing urban knowledge architectures. Future research in this field is proposed which is nuanced, grounded in explicit weightings of different democratic values, and which mediates between recognition of contingency and the ability to undertake comparative analysis.
\end{abstract}

\section{Keywords}

coproduction; knowledge production; participation; urban governance

\section{Issue}

This editorial is part of the issue "Co-Producing Urban Governance for Social Innovation, edited by Liz Richardson (University of Manchester, UK).

(C) 2018 by the authors; licensee Cogitatio (Lisbon, Portugal). This article is licensed under a Creative Commons Attribution 4.0 International License (CC BY).

\section{Introduction}

This thematic issue looks at the theory and practice of coproduction as approaches to governance for 21st century cities. Much about existing forms of urban governance is not fit for purpose, not fully inclusive or just (Fainstein, 2010; Marcuse et al., 2011), nor delivered prosperity for the most disadvantaged. The 20th century prescriptions of 'good governance' and 'trickle down' have not delivered (Perry \& May, 2011) and are insufficient to deal with the contemporary 'urban polycrisis' (Swilling \& Annecke, 2012). Pre-occupations with finding an 'organisational fix' for urban governance has led to a proliferation of different organisational forms. Few have delivered fully on promises of democratisation (Davies, 2011; Harvey,
1989; Logan \& Molotoch, 2007; Purcell, 2008). However, while critiques of existing forms identify what might be wrong with urban governance, there are as many areas of contestation about alternatives as there are suggestions for alternatives. There is a gap in understanding of parsimonious solutions across different contexts to address wicked governance dilemmas (Jones \& Ward, 2002; Offe, 1984), and how there can be a reconnection of local expertise, innovation and creativity in urban policy.

To understand how alternative governing spaces may be constituted, we draw on debates about coproduction, while mindful of the contested lineage of the term, which has been deployed as a mobilising narrative both within and outside academia (Durose \& Richardson, 2016; Vershuere, Brandsen, \& Pestoff, 2012). Achieving effective 
coproduction in urban governance is often a highly complex task and one 'ridden with challenges' (Teisman, Gerrits, \& van Buuren, 2009, p. 116). Indeed, 'designing institutional arrangements that help induce successful coproductive strategies is far more daunting than demonstrating their theoretical existence' (Ostrom, 1996, p.1080). Neither new governing spaces nor coproduction are sufficient predictors of urban change. There are dangers that the mantra of coproduction serves, inadvertently, to reinscribe 'business as usual', running the risk of co-option and capture. The articles in this collection speak to two sets of key debates in the field: binaries between top down' and 'bottom up' approaches; and knowledge production about coproduction.

\section{Thinking about 'Top Down' and 'Bottom Up' Binaries}

The 21st century city has been predicated on a particular form of technocratic and economic knowledge that constitutes expertise as residing in elite and professional epistemic communities. Political cultures are characterized by relatively stable 'civic epistemologies,' or 'public knowledge ways,' that comprise preferred modes of producing public knowledge and conducting policy deliberation (Jasanoff, 2012, p. 9) initiated, or controlled from the 'top'. This context has given rise to an emergent informal tier of non-state governance actors working across and between different sectors and communities who are experimenting with alternative forms of urbanism (Brenner, Marcuse, \& Mayer, 2012). The commentary in this issue by Sarmiento and Tilly (2018) offers empirical examples of some strategies used by urban informal actors in north and Latin America. Successful coproductive arrangements are often generated out of informal spaces and relationships (Fung, 2001) from the 'bottom'. As Wagenaar and Wood (2018) discuss, the literature distinguishes between government-induced and bottom-up interactive governance. A renewed focus on the 'everyday' has shown its potential as a space for radical transformation (Bang, 2005; Cooper, 2014,). This has usefully highlighted the value of prosaic interactions, and microdynamics in complex social realities. However, there is a risk of a critique of conventional governance forms leads to alternative theories of governance which reify the everyday in place of a reification of the local state (Davies, 2011). In Perry, Patel, Bretzer and Polk's (2018) article, local contextualisation, they warn, can work against global connection. Context-sensitivity butts up against 'equal concern' about the 'fetishization of the local'. More than this, is the binary itself a useful heuristic, or a false dichotomy? Of course, as Sarmiento and Tilly (2018) suggest, different processes of coproduction operate on a spectrum, with degrees of orientation towards state actors, which they refer to as a continuum of 'radicalism'. Actors may move between modes or strategies, but they remind us that even those seeking to opt out of state-led processes often must contend with the state. How can we understand how these binary or continuum notions are constructed in theory and practice in different governance settings?

In Wagenaar and Wood (2018), innovation, for example in governance, is argued to be public, but not necessarily limited to the public sector. They describe how experiments in collaborative governance 'emerge in the civic sphere, and transfer to political society'. Citizens have been demonstrated to be 'restless' and 'uninvited' innovators (Hirst, 1994, p. 105). Privileging the bottom up sphere, they make the claim that innovative potential' is premised on the origins of initiatives in the 'free spaces' of civil society.

In Atkinson, Dörfler and Rothfuß (2018) empirical study, there remained in the perceptions of some local activists, a clear separation between 'from below' governance efforts through self-organisation, and existing 'mainstream' governance institutions. Two of their four groups felt the need to protect their practical governance efforts against elite capture, and rejected prevailing governance forms, which were seen to be 'part of the problem'. In place of existing structures was exemplification through practice, including 'laboratories for utopias'. Except for one group, their participants had little or no desire to engage with existing forms of governance or to transform it. The authors argue that these alternatives subvert existing governance forms and offer "new ways of 'governing from below'".

In Atkinson et al. (2018) and in the article by Silver (2018), we can see reflected the idea that local practices are exploiting 'cracks and fissures' in systems (Holloway, 2010). He argues that far from being prosaic, the everyday can contribute to the transformation of governance. Everyday citizens engage only sporadically in governance, and those expert citizens who do are increasingly disconnected from other citizens (Bang, 2005). As with Atkinson et al. (2018), local practice is an opportunity for learning about possible alternatives or 'utopias'. Attempting to avoid accusations of reification of the everyday, he posits the idea of municipal radicalism, giving a key coordinating role to the local state.

In distinguishing between top down and bottom up approaches, Silver (2018) and Atkinson et al. (2018) discuss the role played by critique of existing forms, disruptions to dominant discourses, and the role of dissensus. Wagenaar and Wood (2018) steer us to a consideration of outcomes to adjudicate tensions and conflicts over the social value of innovations. Dean (2018) asks how some of the distinctive features of challenge might be brought into existing institutions, to engage more constructively with 'citizen resistance'. Building on Rosanvallon (2008), he proposes the institutionalisation of 'agonistic participatory practices', such as oversight and scrutiny into existing institutions. This is a crucial debate in relation to concerns about the risks of co-option in coproduction, but also offers an analytical challenge to the binary, or that bottom up approaches have a monopoly on particular characteristics of challenge and critique. As Dean (2018) points out: 'elevation of collaboration...to a 
paradigmatic value means that collaborative governance has a complicated, often confused, relation to conflict'. He reminds us that agonistic practices, such as separation between the executive and legislature, are already well-established within institutions, but primarily used for elite contestation. Dean (2018) suggests a series of practical ways that these ideas might be developed in governance, such as strengthening a city-level right to petition, as a means of popular prevention of impropriety in decision-making.

\section{Knowledge Production about Coproduction}

For Sheila Jasanoff (2004) coproduction is a proposition that the ways in which we know and represent the world are inseparable from the ways we choose to live in it. Coproduction implies multiple forms of expertise and knowledge, bringing new or additional perspectives as befits complex wicked policy issues. Jasanoff's coproduction idiom relates to society as a whole (May \& Perry, 2010), driving new demands for forms of knowledge production about coproductive governance, that are themselves coproductive. New urban governing spaces need to be coproduced through 'participative transformation' (Klev \& Levin, 2012) requiring experimentation and innovation in re-designing urban knowledge architectures.

The articles by Silver (2018) and Atkinson et al. (2018) start to speak to the nature of knowledge production in this field. Both are proponents in their articles of the value of experiential expertise and local knowledge. For Silver, this is not about understanding the 'texture' of lived experience per se, but understanding the radical potential in everyday practices. 'Knowledge' about possible radical futures is generated by reflection on everyday life, and people's strategies for adapting to everyday challenges, which act as 'a critique of the present', as well as opening up alternatives. For Atkinson et al. (2018), knowledge is about sense-making by actors involved in governance, as well as their capacities to act. Within sense- and meaning-making processes, narratives are recognised for their 'generative nature'. They paint a picture of a fierce battle between dominant and alternative forms of knowledge. Some environmental activists viewed dominant knowledge forms with 'a general suspicion, if not outright rejection', and posed 'locally generated knowledge based in everyday life', and demonstrations in local practice, as alternatives to participation in governance. Sarmiento and Tilly (2018) show how claims to particular kinds of knowledge and identity are mobilised as a strategy to lever urban justice.

Perry at al.'s (2018) article here explicitly addresses the challenges of forms of knowledge production which mirror the challenges of coproductive urban governance in the modes of inquiry. This work is produced by a diverse set of authors across the global north and south. It offers a rich empirical insight; as the authors point out: 'theory is catching up with practice' in innovation on coproducing knowledge for urban sustainability. Their ar- ticle describes an international partnership of four local interaction platforms (LIPs). In the LIPs, attempts were made to make 'urban governance more fit-for-purpose' by opening up "coproductive "boundary spaces", designed to 'enable the knowledge and expertise of different participants to be recognised', without privileging any one form of expertise. The experiences of the LIPS suggests, they argue, that approaches are needed which bridge and iterate between local practices, grounded in specific contexts, and shared knowledge about addressing common urban governance challenges. Reflecting on their experiences, they note the serious challenges of fulfilling the principles of coproduction, for example describing tensions between the centre and the local platforms.

\section{Conclusion}

There is much food for thought offered in the articles about where studies of coproduction might go next in specific areas. Perry et al. (2018) caution that there has been "insufficient critical examination of the presumed 'neutrality' or 'safeness' of new boundary spaces", and suggest this as a future research agenda. Dean (2018) proposes exploration of how collaborative and agonistic practices may be combined in governance, and under what conditions difference forms may be more appropriate.

Beyond this, there are three noticeable underlying approaches that run through all of the articles in the thematic issue. The first is a grounding in epistemological traditions of pragmatism. It is perhaps no surprise that ideas of iterative processes of dialogue in knowledge are seen as compatible with studies of coproduction. Secondly, closely linked to this is a strong normative streak in all of the articles, in more or less explicitly articulated ways. Future research needs to wrestle with the challenges, and opportunities, that a normatively-informed and openended positioning offers to studies of coproduction. Wagenaar and Wood (2018) raise the problem of essentialism, and Sarmiento and Tilly (2018) warn against reification; the articles all speak, in different ways, to the highly contingent nature of coproduction. Recognition of complexity and contingency is a third underlying theme. However, the desire to understand coproduction beyond a series of interesting but contingent cases remains. We look forward to seeing more nuanced understandings of coproduction which are grounded in explicit weightings of different values, and broker between contingency and comparative analysis.

\section{Conflict of Interests}

The authors declare no conflict of interests.

\section{References}

Atkinson, R., Dörfler, T., \& Rothfuß, E. (2018). Selforganisation and the co-production of governance: 
The challenge of local responses to climate change. Politics and Governance, 6(1), 169-179.

Bang, H. (2005). Among everyday makers and expert citizens. In J. Newman (Ed.), Remaking governance: Peoples, politics and the public sphere (pp. 159-179). Bristol: Policy Press.

Brenner, N., Marcuse, P., \& Mayer, M. (Eds.). (2012). Cities for people, not for profit: Critical urban theory and the right to the city. London: Routledge.

Cooper, D. (2014). Everyday utopias. Durham, NC: Duke University Press.

Davies, J. (2011). Challenging governance theory: From networks to hegemony. Bristol: Policy Press.

Dean, R. J. (2018). Counter-governance: Citizen participation beyond collaboration. Politics and Governance, 6(1), 180-188.

Durose, C., \& Richardson, L. (2016). Designing public policy for co-production. Bristol: Policy Press.

Fainstein, S. (2010). The just city. Cornell, NY: Cornell University Press.

Fung, A. (2001). Accountable autonomy: Toward empowered deliberation in Chicago schools and policing. Politics and Society, 29(1), 73-103.

Harvey, D. (1989). From managerialism to entrepreneurialism: The transformation in urban governance in late capitalism. Geografiska Annaler, 71B, 317.

Hirst, P. (1994). Associative democracy: New forms of economic and social governance. Cambridge: Polity Press.

Holloway, J. (2010). Crack capitalism. London: Pluto Books.

Jasanoff, S. (Ed.). (2004). States of knowledge: The co-production of science and social order. London: Routledge.

Jasanoff, S. (2012). Science and public reasons. London: Routledge.

Jones, M., \& Ward, K. (2002). Excavating the logic of British Urban policy: Neoliberalism as the 'crisis of crisis management'. Antipode, 34(3), 473-494.

Klev, R., \& Levin, M. (2012). Participative transformation: Learning and development in practising change. Aldershot: Gower.

Logan, J., \& Molotoch, H. (2007). Urban fortunes: The political economy of place. Berkeley, CA: University of California Press.

Marcuse, P., Connolly, J., Novy, J., Olivo I., Potter, C., \&
Steil, J. (2011). Searching for the just city. Debates in urban theory and practice. London: Routledge.

May, T., \& Perry, B. (2010). Social research and reflexivity. London: Sage.

Offe, C. (1984). Contradiction of the welfare state. London: Hutchinson.

Ostrom, E. (1996). Crossing the great divide: Coproduction, synergy and development. World Development, 24(6), 1073-1087.

Perry, B., \& May, T. (2010). Urban knowledge exchange: Devilish dichotomies and active intermediation. International Journal of Knowledge-Based Development, 1(1), 6-24.

Perry, B., \& May, T. (2011). Case studies. In T. May (Ed.), Social research: Issues, methods and process (4th ed.). Maidenhead, Berks: Open University Press.

Perry, B., Patel, Z., Bretzer, Y. N., \& Polk, M. (2018). Organising for co-production: Local interaction platforms for urban sustainability. Politics and Governance, 6(1), 189-198.

Purcell, M. (2008). Recapturing democracy: Neoliberalization and the struggle for alternative urban futures. New York, NY: Routledge.

Rosanvallon, P. (2008). Counter-democracy: Politics in an age of distrust. Cambridge: Cambridge University Press.

Sarmiento, H., \& Tilly, C. (2018). Governance lessons from urban informality. Politics and Governance, 6(1), 199-202.

Silver, D. (2018). Everyday radicalism and the democratic imagination: Dissensus, rebellion and utopia. Politics and Governance, 6(1), 161-168.

Swilling, M., \& Annecke, A. (2012). Just transitions. Explorations of sustainability in an unfair world. Tokyo: United Nations University Press.

Teisman, G., Gerrits, L., \& van Buuren, A. (2009). An introduction to understanding and managing complex process systems. In G. Teisman, A. Buuren, \& L. Gerrits (Eds.), Managing complex governance systems. Oxon: Routledge.

Vershuere, B., Brandsen, T., \& Pestoff, V. (2012). Coproduction: The state of the art in research and the future agenda. Voluntas, 23(4), 1083-1101.

Wagenaar, H., \& Wood, M. (2018). The precarious politics of public innovation. Politics and Governance, 6(1), 150-160.

\section{About the Authors}

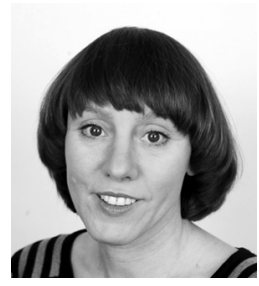

Liz Richardson is a Reader in Politics at the University of Manchester, UK. Her research interests include: decentralised urban governance; public policy; citizen participation; and participatory research methods. Her work has appeared in a range of journals including the British Journal of Politics and International Relations, Social Science Quarterly, Social Policy and Administration, Politics and Governance, and Policy and Politics. 


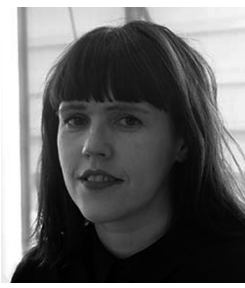

Catherine Durose is Reader at the Institute of Local Government Studies at the University of Birmingham.

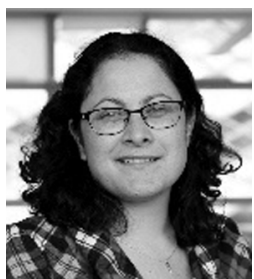

Beth Perry is a Professorial Fellow at the Urban Institute and Urban Studies and Planning, University of Sheffield. Her work focusses on coproduction, urban governance and the just city. She has recently co-authored two books with Tim May on Reflexivity: An Essential Guide (Sage) and Cities and the Knowledge Economy: Promise, Politics and Possibility (Routledge). She is leading a multi-million programme of work (2016-2019) on Realising Just Cities with funding from Mistra Urban Futures and the Economic and Social Research Council. 